\title{
Sensory Problems in Turkish Children with Autism Spectrum Disorder
}

\section{Otizmli Türk Çocuklarının Duyusal Problemleri}

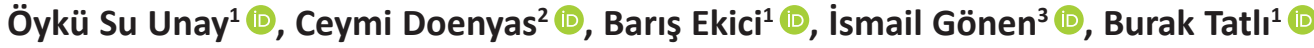

${ }^{1}$ Private Pediatric Neurology Clinic, Istanbul, Turkey

${ }^{2}$ Koç University, Research Center for Translational Medicine, Istanbul, Turkey

${ }^{3}$ Istinye University, Liv Hospital Ulus, Istanbul, Turkey

ORCID ID: Ö.S.U. 0000-0002-6856-6751; C.D. 0000-0002-4809-8719; B.E. 0000-0002-0525-2018; i.G. 0000-0002-5311-5368; B.T. 0000-0002-8965-6668

Citation/Atff: Unay OS, Doenyas C, Ekici B, Gonen I, Tatli B. Sensory problems in Turkish children with autism spectrum disorder. Çocuk Dergisi - Journal of Child 2020;20(2):59-65. https://doi.org/10.26650/jchild.2020.2.773059

ABSTRACT

Background: Sensory problems are a core symptom of autism spectrum disorder (ASD) and tailoring the interventions according to sensory profiles yields better prognosis.

Objective: This study profiled the sensory symptoms of children with ASD and their sociodemographic and behavioral correlates.

Material and Methods: The sample included 911 Turkish children with ASD (748 male and 163 female) aged between 1-18 years. The study was conducted as an internet survey.

Results: Almost all children had a sensory problem in at least one sensory domain. The parents stated that almost half of the children received sensory integration therapy (SIT) and that 3 out of 4 of these children benefited from this method. The rate of receiving SIT for their children with ASD was higher in children of mothers and fathers who had higher education levels. Two out of 3 parents reported that their children have hyperactivity, sleep problems, and food selectivity. Obsessive behaviors were 2 times higher in children with ASD who took non-food objects in their mouths, and almost 7 times more common in children who watched rotating objects. The rates of spinning around themselves, taking nonfood objects in their mouths, and hyperactivity were significantly higher in children who experienced sleep-related problems.

Conclusion: This study documents the sensory problems of Turkish children with ASD and how they relate with other behavioral domains, which can be useful for determining the most appropriate therapeutic approaches.

Keywords: Autism spectrum disorder, sensory integration, sensory problems, sensory processing disorder, Turkish children öz

Amaç: Duyusal sorunlar, otizm spektrum bozukluğu (OSB)'na sıklıkla eşlik etmektedir. OSB'ye yönelik müdahaleleri bireylerin duyusal profillerine göre adapte etmek daha iyi bir prognoz sağlayabilir. Bu çalışma, OSB'li çocukların duyusal semptomlarını ve bu semptomların onların sosyodemografik ve davranışsal özellikleri ile ilişkilerini incelemiştir.

Gereç ve Yöntem: Örnekleme, 1-18 yaşları arasındaki 911 Türk OSB'li (748 erkek ve $163 \mathrm{kIz}$ ) çocuk dahil edilmiştir. Çalışma, bir internet araştırması olarak gerçekleştirilmiştir.

Bulgular: Dahil edilen çocukların neredeyse tamamının en az bir duyusal alanda problem yaşadığı, ebeveynleri tarafından bildirilmiştir. Ebeveynlerin yarısı, çocuklarının duyusal bütünleme terapisi (DBT) aldığını ve alan çocukların 4'te 3'ünün bu yöntemden yararlandığını belirtmiştir. DBT alma oranının, yüksek eğitim düzeyine sahip annelerin ve babaların çocuklarında daha yüksek olduğu görülmüştür. Her 3 ebeveynden 2'si çocuklarında hiperaktivite, uyku sorunu ve gıda seçiciliği durumlarının görüldüğünü bildirmiştir. Ayrıca, obsesif davranışların, ağızlarında yiyecek olmayan cisimleri alan OSB'li çocuklarda 2 kat, dönen cisimleri izleyen çocuklarda ise yaklaşık 7 kat daha fazla görüldüğü belirlenmiştir. Uykuya bağı problemler yaşayan çocuklarda, kendi etrafında dönme, ağızlarında yiyecek olmayan nesneler alma ve hiperaktivite oranları anlamlı derecede yüksek bulunmuştur.

Sonuç: Bu çalışma, OSB'li Türk çocuklarının duyusal sorunlarını ve bu sorunların diğer davranışsal alanlarla ilişkilerini göstermektedir. Böylece, OSB'li bireyler için en uygun terapötik yaklaşımlara yönlendirmelerini sağlamakta fayda sağlayabileceği düşünülmektedir..

Anahtar Kelimeler: Otizm spektrum bozukluğu, duyu bütünleme, duyusal problemler, duyusal işlemleme bozukluğu, Türk çocukları 


\section{INTRODUCTION}

Autism spectrum disorder (ASD) is often accompanied by global sensory dysfunction in the multiple domains of auditory, visual, touch, and oral sensory processing (1). Atypical sensory processing in ASD is reported at a rate between $82 \%$ $97 \%$ in different studies, which is significantly related to the adaptive behaviors displayed by these individuals (2), their sleep disturbances, emotional and behavioral problems, and abnormal mealtime behaviors (3). Therefore, understanding atypical sensory processing in ASD is not only important to have a more complete understanding of this disorder, but also for practical purposes such as improving the adaptive behaviors, behavioral and emotional problems, mealtime behaviors, and sleep problems of individuals with ASD. Though the higher prevalence of sensory processing abnormalities in ASD has been widely reported previously, the relationship of these abnormalities with other characteristics of individuals with ASD has been less frequently investigated, with certain reports documenting the strong relationship between hypersensitivity toward touch and sleep problems (4), positive associations of general and visual sensory hyperreactivity and social skills impairments with insomnia severity (5), and atypical oral sensory sensitivity with more food selectivity (6). Therefore, the purpose of the present study was to explore the demographic and behavioral correlates of sensory processing problems in children with ASD. Such investigations can help understand how sensory sensitivity that prevalently accompanies ASD relates to other relevant domains for this condition and therefore reach a more complete picture of this condition for which many unknowns still exist.

\section{METHODS}

\section{Participants}

Parents of 911 children with ASD aged between 1-18 responded to questions about their children. The inclusion criterion was having received an ASD diagnosis by a Turkish child psychiatrist. The exclusion criterion was being over the age of 18. Eight children with ASD were over 18 and removed from the sample.

\section{Materials and Procedures}

This study was conducted as an internet survey in a social network called "The Autism Brotherhood" where members are parents of children with ASD, between December 2018 and April 2019. At the beginning of the study, it was stated that if parents had more than one child with ASD, they should answer the questions separately for their children, id est fill the form again for the second child. The survey contained questions that were composed from the authors' own clinical experience in their pediatric neurology clinic with children with ASD for over 15 years and from the most researched topics about ASD. The questions were selected from the most common problems reported b y parents of children with ASD. These questions inquire whether the children receive sensory integration therapy ( SIT), if they benefit from it, and also their sensory dysfunctions in different domains such as auditory, visual, vestibular, proprioception, interoception, touch, and oral sensory processing. In the auditory area, the presence of repeating the same sounds, repetitive singing, humming behaviors, and disturbances from everyday domestic sounds such as vacuum cleaners, hair dryers, or siphons, in the visual area, presence of watching rotating objects in the vestibular area, the presence of turning behaviors around themselves and hyperactivity, in the proprioceptive area, the presence of repetitive movements with their hands or arms such as flapping or stimming, giving less intense responses to pain or harm and also receiving massage therapy, in the interoceptive area, the presence of constipation, in the touch area, the presence of tactile defensiveness that cause problems in self-care areas such as bathing, nail cutting, dressing, in the oral area, the presence of taking non-food objects in their mouths and their food selectivity, were investigated. In addition to these questions, sociodemographic characteristics and parents and ch ildren 's accompanying conditions such as obsessions, inappropriate sexual behaviors, harming behaviors, and psychiatric medication use were also examined in this survey.

\section{Statistical Analyses}

IBM Statistics SPSS Version 20 program was used for the statistical analyses conducted to evaluate the findings of the study. Descriptive statistical methods were used to define the study data. Pearson chi-square test and risk estimates were used for comparisons. The significance of all statistical procedures was accepted as $p<0.05$.

\section{Ethical Approval}

Ethical approval was obtained from the Institutional Review Board of Istinye University, meeting number 2020/8, decision number 03. Informed consent was obtained from the parents of the children before starting the survey. Parents were informed that the data of the study will remain confidential and will not be used anywhere other than the study, and no identifying information was asked about them or their children with ASD All the procedures of this study have been prepared by adhering to the Helsinki Declaration and other ethical standards.

\section{RESULTS}

The sample comprised 911 Turkish children with ASD, with 748 (82.1\%) males and 163 (17.9\%) females, corresponding to a male-to-female ratio of $4.6: 1$ that aligns with the global trend. The age of the children ranged from 1 to 18 years, with an average age of $7.22 \pm 4.25$ years $98.2 \%$ of parents responded positively to at least one sensory dysfunction question.

\section{Sensory Integration Therapy History and Related Factors}

Parents reported that 386 (42.4\%) of children with ASD received SIT at least once. When asked if their children benefited from SIT, 302 (78.2\%) parents said yes. The rate of receiving SIT was significantly lower in children of mothers with a low education level. And also, the rate of receiving SIT was significantly higher in children with ASD whose fathers had higher education levels compared to those whose fathers had lower education levels. The rate of reported benefiting from SIT was significantly higher in the children of parents who first noticed a problem with their children before 24 months of age. 
The Distribution of Sensory Dysfunctions and Related Factors: Age, Age of Diagnosis, Repetitive Behaviors, Taking Non-food Objects to Mouths, Hyperactivity, Receiving Massage Therapy In DSM-5, ASD symptoms are categorized under two main headings: persistent deficits in social communication and social interaction; and restricted, repetitive patterns of behavior, interest, or activities ( 7 ). Under the latter, the following are listed: hyper- or hypo-reactivity to sensory input or unusual interest in sensory environmental aspects, and stereotyped or repetitive motor movements, use of objects, or speech. As sensory problems were categorized under repetitive behaviors in DSM-5, it is likely that these types of motor behaviors may have a sensory component. When we asked the parents whether their child was making repetitive movements with their hands or arms, the parents replied 506 (55.5\%) said yes, and 405 (44.5\%) said no. These repetitive motor movements are thought to be related to other repetitive motor movements. The rate of performing repetitive movements with hands or arms was found to be significantly higher in children with ASD who take non-food objects to their mouths. The parents were also asked whether their child gave less intense responses to pain or harm when they fell or hurt. In those children who give less intense responses to pain or harm, repetitive movements with their hands or arms were determined to be significantly higher. In children with ASD who have hyperactivity, repetitive movements with their hands or arms were found to be significantly higher. In children with ASD who have ever received massage therapy, the rate of displaying repetitive movements with their hands or arms was significantly higher. When we asked whether their children exhibited echolalia or repetitive singing behavior, 565 (62\%) said yes, and $346(38 \%)$ said no. When asked if their child watched rotating objects, which is another repetitive behavior in children with ASD, 384 (42.2\%) of the parents said yes, and 527 (57.8\%) said no. The boys with ASD included in this study were significantly more likely to watch rotating objects than girls. When asked if their child displayed turning/spinning behavior around themselves, 275 (30.2\%) of the parents said yes, and 636 (69.8\%) said no. In children with ASD who d i s p I a y e $d$ spinning behavior around themselves, the likelihood of watching rotating objects was significantly higher. In children with ASD who also have hyperactivity, the rate of watching rotating objects was significantly higher. Children with ASD often experience different difficulties related to the oral area such as food selectivity, chewing, and brushing their teeth. Another common oral problem in children with ASD is taking non-food objects in their mouths. When we asked the parents whether their child with ASD is taking non-food objects in his/ her mouth, 440 (48.3\%) said yes, and 471 (51.7\%) said no. When asked whether their child is a picky eater, 625 (68.6\%) of the parents said yes, and 286 (31.4\%) said no. Selective eating problem was significantly higher in boys with ASD than in girls. Additionally, the problems experienced in the oral area relate with each other. The rate of taking non-food objects in their mouths was significantly higher in children with ASD who are picky eaters. There are studies investigating the effectiveness of massage on sensory symptoms, sleep problems, and hyperactivity in children with ASD, and many of these studies have shown massage benefits for children with ASD in different developmental areas. In this sample, when we asked the parents if their child with ASD ever received massage therapy, 157 (17.2\%) said yes, and 754 (82.8\%) said no. The rate of having ever received massage therapy was significantly higher in boys than in girls. The rate of receiving massage therapy was significantly higher in children of mothers with a high education level. Children with ASD give less intense responses to pain or harm. It is thought that this condition may be related to weak body awareness. When asked whether their child gives less intense responses to pain or harm, 408 (44.8\%) said yes, and 503 (55.2\%) said no. The children who have weak body awareness could experience challenges when sitting on the toilet and calming themselves and they may also show self-stimulating behaviors. In children with ASD who were reported by their parents to give less intense responses to pain or harm, the rate of failure to achieve toilet training on time was significantly higher. In children who take non-food objects in their mouths, the rate of giving less intense responses to pain or harm was significantly lower. In children with ASD who also have hyperactivity, the rate of giving less intense responses to pain or harm was significantly higher. In children with ASD who have ever received any message therapy, the rate of giving less intense responses to pain or hurt was significantly lower.

One of the other most common conditions in ASD is hyperactivity. In this sample, when asked if their child has hyperactivity, 632 (69.4\%) parents said yes, and 279 (30.6\%) said no. Children with ASD who have hyperactivity often exhibit different types of self-calming behaviors. In children who have hyperactivity, the rate of taking non-food objects in their mouth was significantly higher. In children with ASD who have hyperactivity, The rate of having received massage therapy at least one time in their life was significantly higher.

\section{Conditions Accompanying Sensory Dysfunction: Obsessions, Sleeping Problems, Inappropriate Sexual Behaviors, Harming Behaviors, and Psychiatric Medication Use}

Another common problem in ASD is obsessive behaviors and these behaviors are thought to be related to many sensorybased repetitive behaviors. In children with ASD who perform repetitive movements with their hands or arms, the rate of having obsessive behaviors was significantly higher. In this sample, the rate of obsessive behaviors was 6.84 times higher in children with turning/spinning behavior around themselves. There was a significant positive relationship between having obsessive behaviors and watching rotating objects. The rate of obsessive behaviors was significantly higher in children with repetitive sounds, singing, muttering behaviors.

The rate of obsessive behaviors was 2 times higher in children who take non-food objects in their mouths. It was also significantly higher in children with ASD who give less intense responses to pain or harm. In children with ASD with hyperactivity, the rate of having obsessive behaviors was significantly higher. In children who ever received massage therapy, the likelihood of having obsessive behaviors was 
significantly higher. Children with ASD experience sleep-related problems such as falling asleep and staying asleep, which may be related to their hyperactivity or self-regulation problems. In this sample, when we asked the parents of children with ASD whether their child had ever experienced any sleep-related problems such as falling or staying asleep, 654 (71.8\%) said yes and $257(28.2 \%)$ said no. The rate of repetitive movements with hands or arms was significantly higher in children with ASD who have experienced sleep-related problems. The rate of ever experiencinged any sleep problems was significantly higher in children with turning/spinning behavior around themselves. The rate of taking non-food objects in their mouths was significantly higher in the group with sleep problems. In children with ASD who have hyperactivity, the rate of having experienced sleep-related problems was significantly high. The rate of receiving massage therapy at least one time in their life was significantly higher in children who have experienced sleep-related problems. Masturbation is an inappropriate sexual behavior (ISB) in ASD that is believed to relate to selfregulation and emotional-social self-stimulation. The rate of benefitting from SIT was significantly higher in children with ASD who have ISB. And also, the rate of repetitive movements with hands and arms was significantly higher in children with ISB. The rate of giving less intense responses to pain or harm was significantly higher in children with ASD who have ISB. ISBS were significantly higher in children who have hyperactivity. Self-harming behaviors or harming behaviors towards others are commonly seen in children with ASD. It is thought that one reason underlying such behavior may be to stimulate themselves with tactile or proprioceptive input. In children performing repetitive motor movements with their hands or arms, self-harming behavior was significantly higher. Selfharming behaviors were significantly higher in children with ASD who take non-food objects in their mouths. The rate of giving less intense responses to pain or harm was significantly higher in children with ASD displaying self-harming behaviors. Self-harming behaviors were also significantly higher in children with ASD who have hyperactivity. The rate of harming behavior towards others was significantly higher in children who take non-food objects in their mouths. The rate of harming behavior towards others was significantly higher in children who give less intense responses to pain or harm. The rate of harming behaviors towards others was significantly higher in children with ASD who also have hyperactivity. Psychiatric medication is used for behavioral and sensory problems in children with ASD. The rate of repetitive movements with hands and arms was significantly higher in children who use psychiatric medication.

The rate of giving less intense responses to pain or harm was significantly higher in children who use psychiatric medication. There is a significant positive relationship between psychiatric medication us and hyperactivity.

\section{DISCUSSION}

Sensory problems in children with ASD may be related with different physiological conditions such as nutrition, constipation, hyperactivity, and sleeping (8-12). A clear understanding of the relationships between physiological conditions and sensory problems is important for planning and constructing the appropriate educational and therapeutic approaches for individuals with ASD in the early period. The questions of our study were chosen among the most common sensory-based problems based on our clinical experience. It investigates a less frequently studied topic in the literature, which is the relationship between the socio-demographic characteristics, accompanying medical conditions, and sensory problems. There are differences regarding the definitions for sensory integration intervention. Some studies define these therapeutic approaches as sensorybased intervention programs, while others define them as SIT (13). When composing the questions in this survey, the preferred usage was "SIT" because it is a commonly used term by parents of children with ASD in Turkey. It was found that nearly half of the children with ASD (42.4\%) included in this study received SIT. It has been stated that the rate of children with ASD who receive sensory interventions was over $45 \%$ in some studies (14) and over $60 \%$ in some others (15). Compared to the literature, the rate of receiving SIT in Turkey was lower. This difference may be because in Turkish health insurance systems, sensory-based intervention programs are not covered. When other factors that might be related to receiving sensory intervention programs were examined, it was determined that the rate of receiving SIT was higher in children of mothers and fathers who noticed the risks in their child before 24 months and who had higher education levels. This may be because parents who were highly educated recognize the developmental risks in their children earlier, and are likely to be more knowledgeable about different therapeutic approaches for ASD. Previous studies reveal that sensory-based approaches have different positive effects on children with $\operatorname{ASD}(13,16)$. When the rate of benefitting from sensory integration intervention was examined, parents reported that 3 out of 4 children (78.2\%) gained positive effects from the method. The results from the literature and this study seem to be paralleled in that children with ASD benefit from sensory-based interventions. Therefore, it may be recommended that policies need to be developed for children with ASD to reach cost-effective sensory-based therapy. Under the repetitive behavior diagnostic criterion of ASD, sensory symptoms are defined as "hyper or hyporeactivity to the sensory inputs or unusual sensory interests" (7). Based on this, it can be said that repetitive behaviors may have a sensory component (17). Our study results showed that the behavior of repetitive movements with hands and arms was observed in more than half of the children (55.5\%). It was found that these types of behaviors have a significant relationship with other sensory- based behaviors such as taking non-food objects in their mouths, giving less intense responses to pain or harm, self-harming, and hyperactivity behaviors. Also, it was concluded that rates of psychiatric medication use, obsessive, and inappropriate sexual behaviors were higher in children in children with sensory problems. Self- harming behaviors and hyperreactivity in children with 
ASD may be related to self-regulation (18). In the present study, the rate of receiving massage therapy was significantly higher in children who have repetitive movements with hands and arms. This might be because parents prefer massage therapy as a solution for repetitive movements of their children. And also, it was found that 1 in 5 (17.2\%) children had received massage therapy in this study. The rate of receiving massage therapy was significantly higher in boys than girls, and in children of mothers who are highly educated. In the literature, it has been reported that massage helps to self-regulate and reduce ASD symptoms (19), which may assist to reduce sensory sensitivity behaviors (20), and stereotypical movements (21).

Based on this, the Turkish parents of the children with ASD may have preferred to have their children take massage therapy for developing self-regulation skills, improving body awareness, and reducing repetitive movements in their children. Another common repetitive behavior is watching rotating objects, which was present in almost half of the children (42.2\%) and was more common in boys than girls. It has been noticed that obsessive behaviors were two times more common in children who have the behavior of taking non-food objects in their mouths, and obsessive behaviors were almost 7 (6.87) times more common in children who have the behavior of watching rotating objects. It was concluded that the rate of hyperactivity and massage therapy were also significantly higher in children with ASD who had obsessive behaviors. Two out of 3 parents reported that their children with ASD had hyperactivity. It was noticed that taking non-food objects in their mouths, inappropriate sexual behaviors, psychiatric medication use, and receiving massage therapy are more common in children with ASD with hyperactivity. It has been determined that children with ASD have more food selectivity problems than children with typical development (22) and it was found that children with ASD had atypical oral sensitivity and they refused food and ate fewer vegetables than children with typical oral sensitivity (6). Results from the literature showed that problems in feeding in children with ASD can be improved by including strategies for oral sensory processing (6). The data obtained from this study shows that 2 out of 3 of children (68.6\%) have food selectivity problems. In addition, our study determined that the rate of taking non-food objects in their mouths is a more common problem in children with food selectivity. These findings align with the previously reported relationship between oral problems and selective eating and it could be said that food selectivity is a more common problem in children with ASD who have sensory problems in the oral area. The rate of having experienced sleep-related problems in children with ASD has been reported by parents to range from $40 \%$ to $80 \%$ (22). Similarly, in the present study, 2 out of 3 parents $(71.8 \%)$ included in this study stated that their children experienced sleep-related problems. Based on this, it may be said that a common problem for children with ASD is sleep problems. In this study, it was found that in children who had experienced sleep-related problems, the rate of turning/spinning behavior around themselves, taking non-food objects in their mouths, and hyperactivity were significantly higher. Other studies have shown that sleep problems are more common in children with ASD (23), a $n$ d sleep problems were especially thought to be associated with hyperactivity (24), and hypersensitivity to touch (4). In our study, similar to previous studies in the literature, there was a relationship between the sleep problems and sensory problems of children with ASD. Based on this, it could be said that the sensory problems of children with ASD may be related to sleep problems. In children who experienced sleep problems, the rate of receiving massage therapy was significantly higher. A study reported that massage therapy was beneficial for children with sleep problems (25). It is likely that Turkish parents were also referred to massage therapy for a solution in the sleep problems of their children with ASD. Standardized sensory parent questionnaires are used to determine the sensory problems in individuals with ASD $(26,27)$. Different studies examining sensory problems through these surveys reported that the rate of sensory problems in at least one domain varied between $45 \%$ and $90 \%(17,28,29)$. In this study, the rate of parents of children with ASD responding positively to the questions related to the presence of sensory problems at least in a domain was $98.2 \%$, a rate higher than those previously reported in the literature. This difference might be related to our utilization of a test that is based on clinical experience, rather than the standardized test. Using such independent questions that are not part of a scale may have been a limitation for this study and may have resulted in obtaining a higher rate for sensory problems. In conclusion, this study showed that sensory problems and motor repetitive behaviors in children with ASD may go together, similar to other findings of sensory problems and repetitive behaviors in the literature $(30,31)$. The present results also may suggest that sensory problems might be related to sociodemographic characteristics of children and parents and children's accompanying physio logical, behavior al, and medical conditions. SIT is less widespread in Turkey compared to other countries and Turkish parents prefer to utilize massage therapy for different sensory-based problems of their children with ASD. Considering that three in every four children with ASD receiving SIT were reported to benefit from it, it can be recommended that sensory-based interventions should be covered by the Turkish health insurance systems.

Ethics Committee Approval: This study was approved by the Institutional Review Board of Istinye University. (meeting number: 2020/8.)

Informed Consent: Written consent was obtained from the participants.

Peer Review: Externally peer-reviewed.

Author Contributions: Conception/Design of Study- B.E., Ö.S.U., C.D.; Data Acquisition- Ö.S.U., B.T., I.G.; Data Analysis/Interpretation- B.E., Ö.S.U., C.D.; Drafting Manuscript- C.D., Ö.S.U., I.G.; Critical Revision of Manuscript- C.D., B.E., Ö.S.U., B.T.; Final Approval and AccountabilityC.D., B.E., I.G., Ö.S.U., B.T. 
Conflict of Interest: Authors declared no conflict of interest.

Financial Disclosure: Authors declared no financial support.

Etik Komite Onayı: Bu çalışma İstinye Üniversitesi Kurumsal İnceleme Kurulu tarafindan onaylanmıştı. (toplant numarası: 2020/8.)

Bilgilendirilmiş Onam: Katılımcılardan bilgilendirilmiş onam alınmıştır.

Hakem Değerlendirmesi: Dış bağımsız.

Yazar Katkıları: Çalışma Konsepti/Tasarım-B.E., Ö.S.U., C.D.; Veri Toplama- Ö.S.U., B.T., I.G.; Veri Analizi/Yorumlama- B.E., Ö.S.U., C.D.; Yazı Taslağı- C.D., Ö.S.U., I.G.; İçeriğin Eleştirel İncelemesi- C.D., B.E., Ö.S.U., B.T.; Son Onay ve Sorumluluk- C.D., B.E., I.G., Ö.S.U., B.T.

Çıkar Çatışması: Yazarlar çıkar çatışması beyan etmemişlerdir.

Finansal Destek: Yazarlar finansal destek beyan etmemişlerdir.

\section{REFERENCES/KAYNAKLAR}

1. Kern J, Trivedi MH, Garver CR, Grannemann BD, Andrews AA, SavlaJ $S, \ldots$ and Schroeder JL. The pattern of sensory processing abnormalities in autism. Autism 2006;10(5):480-494.

2. Dellapiazza F, Vernhet $C$, Blanc N, Miot S, Schmidt Rand Baghdadli A. Links between sensory processing, adaptive behaviours, and attention in children with autism spectrum disorder: Asystematic review. Psychiatry Res 2018;270:78-88.

3. Wang J and Wang X. Structurale quation modeling: Application susing Mplus. 2019. John Wiley \& Sons.

4. Tzischinsky O, Meiri G, Manelis L, Bar-Sinai A, Flusser H, Michaelovski $A$, et al. Sleep disturbances are associated with specific sensory sensitivities in children with autism. Mol Autism 2018;9(1):22.

5. Hohn VD, de Veld, DM, Mataw KJ, van Someren EJ and Begeer S. Insomnia severity in adults with autism spectrum disorder is associated with sensory hyper-reactivityand social skill impairment. J Autism Dev Disord 2019;49(5):2146-2155.

6. Chistol LT, Bandini LG, Must A, Phillips S, Cermak SA and Curtin C. Sensory sensitivity and food selectivity in children with autism spectrum disorder. J Autism Dev Disord 2018;48(2):583-591.

7. American Psychiatric Association. (2013). Diagnostic and statistical manual of mental disorders (DSM- ${ }^{\circledR}$ ). American Psychiatric Pub.

8. Nadon G, Feldman DE, Dunn W and Gisel, E. Association of sensory processing and eating problems in children with autism spectrum disorders. Autism Res and Treat 2011, 541926.

9. Schaaf RC, Toth-Cohen S, Johnson SL, Outten G and Benevides TW. The everyday routines of families of children with autism: Examining the impact of sensory processing difficulties on the family. Autism 3252011;15(3):373-389.

10. Mazurek MO, Vasa RA, Kalb LG, Kanne SM, Rosenberg D, Keefer A, ... and Lowery, L. A. Anxiety, sensory over-responsivity, and gastrointestinal problems in children with autism spectrum disorders. J. Abnorm. Child Psychol 2013;41(1):165-176.

11. Little LM, Dean E, Tomchek S and Dunn W. Sensory processing patterns in autism, attention deficit hyperactivity disorder, and typical development. Phys Occupther in Pediatr 2018;38(3):243254.
12. Mazurek MO and Petroski GF. Sleep problems in children with autism spectrum disorder: examining the contributions of sensory over-responsivity and anxiety. Sleep Med 2015;16(2):270-279.

13. Lang R, O'Reilly M, Healy O, Rispoli M, Lydon $H$, Streusand W ... and Didden R. Sensory integration therapy for autism spectrum disorders: A systematic review. Res Autism Spectr Disord 2012;6(3):1004-18.

14. Green VA, Pituch KA, Itchon J, et al. Internet survey of treatments used by parents of children with autism. Res Dev Disabil 2006;27:70-84.

15. Schaaf RC and Case-Smith J. Sensory interventions for children with autism. J comp effect res 2014;3(3):225-227.

16. Case-Smith J, Weaver LL, and Fristad MA. A systematic review of sensory processing interventions for children with autism spectrum disorders. Autism 2015;19(2):133-148.

17. Leekam S, Nieto C, Libby S, Wing L and Gould J Describing the sensory abnormalities of children and adults with autism. J Autism Dev Disord 2007;37(5):894-910.

18. Silva LM and Schalock M. Sense and self-regulation checklist, a measure of comorbid autis symptoms: initial psychometric evidence. Am J Occup Ther 2012;66(2):177-186.

19. Silva LM, Schalock M and Gabrielsen K. Early intervention for autism with a parent-delivered Qigong massage program: a randomized controlled trial. Am J Occup Ther 2016;5(5):550559.

20. Escalona A, Field T, Singer-Strunck R, Cullen C and Hartshorn K. Brief report: improvements in the behavior of children with autism following massage therapy. J Autism Dev Disord 2001;31(5):513516.

21. Bandini LG, Anderson SE, Curtin C, Cermak S, Evans EW, Scampini $R$, et al. Food selectivity in children with autism spectrum disorders and typically developing children. J Pediatr 2010;157(2):259-264.

22. Cortesi F, Giannotti F, Ivanenko A, Johnson K. Sleep in children with autistic spectrum disorder. Sleep Medicine 2010;11(7);659-664.

23. Richdale AL and Schreck KA. Sleep problems in autism spectrum disorders: prevalence, nature, \& possible biopsychosocial aetiologies. Sleep Med Rev 2009;13(6):403-411.

24. Goldman SE, Surdyka K, Cuevas R, Adkins K, Wang L and Malow $B A$. Defining the sleep phenotype in children with autism. Dev Neuropsychol 2009;34(5):560-73.

25. Escalona A, Field T, Singer-Strunck R, Cullen C and Hartshorn K. Brief report: improvements in the behavior of children with autism following massage therapy. J Autism Dev Disord 2001;31(5):513-516.

26. Piravej $K$, Tangtrongchitr $P$, Chandarasiri $P$, Paothong $L$ and Sukprasong S. Effects of Thai traditional massage on autistic children's behavior. J Altern Complement Med 2009;15(12):13551361.

27. Tomcheck SD and Dunn W. Sensory processing in children with and without autism: A comparative study using the Short Sensory Profile. Am J Occup Ther 2007;61(2):190-200.

28. Baker AE, Lane A, Angley MT and Young RL. The relationship between sensory processing patterns and behavioural responsiveness in autistic disorder: A pilot study. J Autism Dev Disord 2008;38(5):867-875. 
29. Baranek GT, David FJ, Poe MD, Stone WL and Watson LR. Sensory experience questionnaire: Discriminating sensory features in young children with autism, developmental delays, and typical development. J Child Psychol Psychiatry 2006;47(6):591-601.

30. Boyd BA, Baranek GT, Sideris J, Poe MD, Watson LR, Patten E and Miller $\mathrm{H}$. Sensory features and repetitive behaviors in children with autismand developmental delays. Autism Research 2010:3(2);78-87.
31. Chen $\mathrm{YH}$, Rodgers $\mathrm{J}$ and McConachie $\mathrm{H}$. Restricted and repetitive behaviours, sensory processing and cognitive style in children with autism spectrum disorders. J Autism Dev Disord 2009;39(4):635-642. 